\title{
A CONTRIBUTION TO THE THEORETICAL STRUCTURE FOR COGNITIVE DYNAMIC CAPABILITY
}

\author{
ELNIVAN M. SOUZA ${ }^{1}$ \\ https://orcid.org/0000-0003-4678-2784 \\ SÉRGIO HENRIQQUE A. C. FORTE \\ (iD) https://orcid.org/0000-0002-8406-0910
}

To cite this paper: Souza, E. M., \& Forte, S. H. A. C. (2019). A contribution to the theoretical structure for cognitive dynamic capability. Revista de Administração Mackenzie, 20(4). doi:10.1590/ 1678-6971/eRAMR190171

Submission: Nov. 10, 2018. Acceptance: Feb. 20, 2019.

1 Centro Universitário Christus (Unichristus), Fortaleza, CE, Brazil.

2 Universidade de Fortaleza (Unifor), Fortaleza, CE, Brazil.

\section{(cc) BY}

This is an open-access article distributed under the terms of the Creative Commons Attribution License.

\begin{abstract}
This paper may be copied, distributed, displayed, transmitted or adapted if provided, in a clear and explicit way, the name of the journal, the edition, the year and the pages on which the paper was originally published, but not suggesting that RAM endorses paper reuse. This licensing term should be made explicit in cases of reuse or distribution to third parties. It is not allowed the use for commercial purposes.

Este artigo pode ser copiado, distribuído, exibido, transmitido ou adaptado desde que citados, de forma clara e explícita, o nome da revista, a edição, o ano e as páginas nas quais o artigo foi publicado originalmente, mas sem sugerir que a RAM endosse a reutilização do artigo. Esse termo de licenciamento deve ser explicitado para os casos de reutilização ou distribuição para terceiros. Não é permitido o uso para fins comerciais.
\end{abstract}




\section{ABSTRACT}

Purpose: The study seeks to contribute to the theoretical structure of cognitive dynamic capability.

Originality/value: The study provides a review of the sources and characteristics of cognitive management capabilities, points out their specific dimensions of analysis, and explores the research possibilities associated with approaches such as strategic changes and the performance of the firm.

Design/methodology/approach: This work uses the concept of mental models, understood as simplified knowledge structures or cognitive representations about the functioning of the business environment to expose the logical chain of theoretical reflections and formulation of propositions.

Findings: The main contributions of this study are: 1 . the reformulation of the concept of cognitive dynamic capability; 2 . the inclusion of the concepts of controlled and automatic mental processing in the proposed model; 3 . the inclusion of the variables experience, time, team confidence and complexity; and 4. the formulation of five propositions to support future research. We suggest an opportunity for research on the relationship between cognitive management capabilities and organizational dynamic capabilities, and their joint contribution to strategic changes in business models and firm performance.

\section{KEYWORDS}

Mental model. Cognitive capability. Management capability. Mental activities. Microfoundations. 


\section{INTRODUCTION}

Recently, discussions in the field of strategy have been directed towards the understanding of cognitive aspects of the managers responsible for organizations' strategic decisions, opening space for theoretical approaches focused on the individual (Powell, 2014), such as neuro-strategy (Powell, 2011) and cognitive management capabilities (Helfat \& Peteraf, 2015).

Therefore, the role of the individual manager assumes greater importance in an emerging literature on the micro-foundations of dynamic capabilities for organizational adaptation and change (Helfat \& Peteraf, 2015; Powell, 2014).

Adner and Helfat (2003) argue that some managers may have "managerial dynamic capability" allowing them to build, integrate, reconfigure, and reposition organizational resources and capabilities. Adner and Helfat (2003) also note that management's dynamic capabilities depend in part on managerial cognition; however, the cognitive foundations of managerial dynamic capability remain largely unexplored (Eggers \& Kaplan, 2013).

Previous studies have shown that heterogeneity of high management cognition is associated with a heterogeneity of efforts and results in strategic changes (Castanias \& Helfat, 1991; Lieberson \& O'Connor, 1972; Zhang, Li, Ullrich, \& Dick, 2015). However, relatively little of this research has focused directly on aspects of the mental activities (or mental processes) of cognition (Helfat \& Peteraf, 2015; Powell, 2011) that involve the acquisition, organization, and processing of information.

Helfat and Peteraf (2015) propose the concept of managerial cognitive capabilities and structure a model for its empirical application, not yet empirically validated. In summary, there is a need for a better understanding of managerial cognitive capabilities in terms of construction, identification, and modeling that allow integration with important areas of strategic knowledge such as strategic changes, business model and firm performance.

An identified shortcoming lies in the little existence of viable methodological procedures for collecting, organizing and analyzing cognitive data in the strategy field (Powell, 2011). Thus, the concept of the mental model is used to expose the theoretical reflections and propositions. The mental model is a simplified knowledge structure or cognitive representation of the functioning of the business environment (Gary \& Wood, 2011). This concept is used to expose the logical connection of the theoretical reflections and formulation of propositions of this study. Therefore, which elements can be added to Helfat and Peteraf's (2015) concept of cognitive dynamic capability? 
The main aim of this paper is to contribute to the theoretical structure of Helfat and Peteraf's (2015) cognitive dynamic capability, defined here as the ability of an individual manager to perform one or more mental activities that comprise cognition. More specifically, this paper: 1. provides a review of the sources and characteristics of management cognitive capabilities; 2. points out their analysis specific dimensions; and 3. explores the possibilities of research related to approaches such as strategic changes, business models and firm performance.

We contribute theoretically to a reformulation of the concept of cognitive dynamic capability by proposing five hypotheses to support future empirical applications and by explaining the role of automatic and controlled mental processes in the theoretical model.

\section{MENTAL ACTIVITIES AND COGNITION AND STRATEGY}

Currently, there are several theoretical streams that seek to understand phenomena linked to research on strategies for the investigation of aspects related to the brain's mental or cognitive activities. Two can be highlighted: neuro-strategy (Powell, 2011) and cognitive dynamic capability (Helfat \& Peteraf, 2015).

Powell (2011) proposes a new field called neuro-strategy, suggesting that researchers seek inspiration in subareas of behavioral neuroscience such as neuroeconomics and neuromarketing. Neuro-strategy consists of analyzing the functioning of the brain of the strategic decision-maker when exposed to manipulated situations.

Research on this subject, as a rule, is undertaken with the use of modern imaging equipment (e.g. magnetic resonance imaging). The subjects of the research are submitted to adverse situations and their brains scanned, the images analyzed according to the cerebral alterations. Strategy theories often use unobserved psychological constructs to explain observed behavior (Powell, 2011). Neuroscience can contribute to social research linking unobserved mental constructs with physiological events in the brain (Powell, 2011).

In recent years, neuroscientists have studied the brain at various levels of analysis - molecular, cellular, systemic and behavioral. Behavioral neuroscience includes disciplines such as neuroeconomics and neuromarketing, which link activity in the brain to reputation, status, cooperation, trust and altruism (social neuroscience); learning, perception, memory, and decision- 
making (cognitive neuroscience); and sensations, passions, feelings and motivational states (affective neuroscience) (Powell, 2011). Clearly, some of these areas address research problems in strategic management and suggest the possibility of linking strategy and neuroscience.

However, there are doubts about whether processes within the brain can actually be configured as the main unit of analysis in strategic management (Rumelt, Schendel, \& Teece, 1994). Some social scientists are not convinced. Gul and Pesendorfer (2008) argue that neuroscience cannot test economic models because economic models cannot predict the brain. Economists often worry about the conditions and choices they make - for example, the impact of a tax increase on savings - rather than the intervening processes (Powell, 2011).

Similar suspicions can be raised about neuro-strategy. One can argue, for example, that neuro-strategy cannot answer strategic questions because strategic management does not ask questions about the brain. Strategy researchers have always been concerned with interposed decision processes, giving equal weight to strategies and performance (Fredrickson \& Mitchell, 1984). If neuroscience gives a genuine insight into the mechanisms of strategic choice, it has direct relevance to strategy research (Powell, 2011).

Another theoretical approach focused on the cognition of the strategist is that of cognitive dynamic capability, proposed by Helfat and Peteraf (2015). In cognitive science, a multidisciplinary field that includes artificial intelligence and cognitive psychology (Luger, 1994), the term "cognition" applies to any kind of mental operation or mental "structure" - not referring to physical structures in the brain (as opposed to neuro-strategy), but to representations of information processed by the brain (Schneider \& Angelmar, 1993).

The term "cognition" encompasses two meanings: 1. mental activities (also called "mental processes" or "mental operations"), and 2. mental structures (or representations). Management research has focused heavily on the second meaning of cognition, also known as knowledge structure (Helfat \& Peteraf, 2015).

In this process of a transition from focusing on tasks and routines to understanding the mental activities of managers who think, idealize and are responsible for executing strategies in an organization, Helfat and Peteraf (2015, p. 835) propose the concept of "cognitive dynamic capability" as "the ability of an individual manager to perform one or more of the mental activities that make up cognition". This definition directs the activities or functions to what can be accomplished by cognition. The human brain 
performs many different mental activities, involving, for example, attention, perception and problem-solving (Helfat \& Peteraf, 2015).

Research in psychology and related fields distinguishes two modes of mental processing of information (Stanovich \& West, 2000). One, predominantly automatic, is called "system 1 mental processing" (Kahneman, 2011; Stanovich \& West, 2000), in which automatic mental activities allow rapid responses to stimuli and external data (Schneider \& Shiffrin, 1977). The other mode of processing is often referred to as "controlled" or "deliberative" mental processing or as an "executive function", called "system 2 mental processing" (Kahneman, 2011; Stanovich \& West, 2000).

Despite Powell's (2011) strong defense of the importance of neurostrategy for the discovery of new knowledge in the area of strategy, this is an area that is still underdeveloped and that convinces few researchers to embark on it. Taking into account that the cognitive dynamic capability approach (Helfat \& Peteraf, 2015) is more developed than neuro-strategy (Powell, 2011), the following sections are developed to promote a better understanding and to describe the empirical operation of cognitive dynamic capability.

\section{COGNITIVE DYNAMIC CAPABILITY}

Cognitive capabilities can improve through practice, a phenomenon that similarly characterizes the development of the capabilities studied in strategic management. For example, Ericsson and Lehmann (1996) found in observational and laboratory studies that memory performance improves with practice and training.

Posner, DiGirolamo, and Fernandez-Duque (1997), for example, consider that practice can change the size or number of brain areas involved and the pathways used in performing "cognitive skills" (e.g. reading) that require attention. Findings like these suggest that if some individuals practice a particular mental activity more often than other individuals (e.g. frequent short-term memory use by waiters), they are likely to develop better cognitive abilities of this type.

The following sections are developed to detail the most relevant elements identified in the literature to explain and describe cognitive dynamic capability.

\subsection{Controlled and automatic mental processes}

The heterogeneity of cognitive capabilities seems to involve both controlled and automatic mental processes (Kahneman, 2011; Stanovich \& 
West, 2000). Research has shown that individuals differ in their dependence on different types of automatic vs. controlled processes (Weber \& Johnson, 2009).

The development of experience initially depends on controlled mental processing (system 2), but mental processing becomes automatic with practice (Larrick \& Feiler, 2016). In particular, practice changes the nature of "cognitive operations", improving the speed and smoothness of mental processing, and so reducing the demands that these operations make on the ability of the brain (Ericsson, 2016). The finding that practice in a particular domain can lead to automation in mental processing suggests that differences between individuals in the extent of prior experience within a domain can lead to heterogeneity in dependence on automatic versus controlled processing.

A greater reliance on automated processes has advantages and disadvantages. As noted, automatic processes improve the speed of mental processes and place less demand on brain capability. However, automatic mental processes can also lead to bias in decision-making (Kahneman, 2011; Kahneman, Slovic, \& Tversky, 1982). Although research suggests that controlled mental processes may have the potential to intervene and nullify such bias (Stanovich \& West, 2000), individuals appear to differ in their ability to do so (Weber \& Johnson, 2009), providing yet another source of heterogeneity in cognitive capabilities.

Thus, we can find studies that seek the approximation between cognition and strategy (Helfat \& Peteraf, 2015; Schilling, 2018). Schilling (2018) presents the cognitive foundations of visionary strategy (abstraction, idealism, path of analytical reasoning), while Helfat and Peteraf (2015) propose a framework in which cognitive dynamic capability comprises perception and attention, problem-solving and rationality, language and communication, and social cognition. In the next sections, we will detail the latter concept, besides contributing to the insertion of the concepts of automatic mental processing (system 1) and controlled mental processing (system 2) that were not included in Helfat and Peteraf's (2015) framework.

\subsection{Perception and attention}

The American Psychological Association (APA) defines perception as the "mental activities or processes that organize information (in the sensory image) and interpret it as having been produced by properties of (objects or) events in the external world (three-dimensional)" (APA, 2018). Perception 
is considered a mental activity closely related to attention, which implies the selection of relevant information (Helfat \& Peteraf, 2015).

In psychology, perception is generally distinguished from sensation, which refers to the experience or subjective feeling that occurs when sensory receptors are activated. Gazzaniga (2014) notes that while the essence of sensation is detection, the essence of perception is the construction of useful and meaningful information about a particular environment. Perception involves a number of mental functions, including those related to pattern recognition (National Advisory Mental Health Council - NAMHC, 1996) and data interpretation (APA, 2018).

Thus, prior cognition, expectations, and belief guide the activities of mental perception. A summary report from the National Advisory Mental Health Council (NAMHC, 1996, p. 133) states that the human brain combines perceptual data of the environment with "knowledge, beliefs, and expectations to make reasonably informed assumptions" about what is present in the environment. With regard to pattern recognition, experts differ from novices (those without knowledge or expertise) "largely in terms of how many standards they can quickly recognize and respond appropriately" (NAMHC, 1996, p. 133).

In a classic study of pattern recognition between experts and novices, Chase and Simon (1973a) asked chess players to perform a perception task that required the reconstruction of a chess position: the study showed that more experienced chess players perceived longer stretches of play - "family or significant constellations of pieces that are already structured in longterm memory" (Chase \& Simon, 1973b, p. 217) - creating faster pattern recognition. As Chase and Simon (1973a, p. 56) have observed, this rapid recognition of patterns depends on the automatic processing accumulated by years of constant practice. Subsequent studies have replicated this phenomenon not only in chess but also in other applications, such as electronic games (Ericsson, 2016).

These studies suggest that context-specific knowledge and experience in pattern recognition may provide an attenuating factor, although subjective beliefs may distort perceptions, particularly when information is ambiguous (Powell, Lovallo, \& Caringal, 2006). Moreover, the fact that knowledge gained from past experience shapes the perception of new experiences points to path dependence: past experiences shape new perceptions, which then become part of the basis of experience for subsequent perceptual activity (Helfat \& Peteraf, 2015).

The cognitive capability of perception affects the perception of opportunities in multiple ways. Recognizing emerging patterns in the environment, 
for example, is essential for the detection of opportunities (George, Parida, Lahti, \& Wincent, 2016). Interpreting these data is also critical for both the recognition and the creation of opportunities.

Rapid recognition or creation of new opportunities is also relevant, particularly if firms can reap long-term benefits (Chen, Delmas, \& Lieberman, 1988). Similarly, pattern recognition can facilitate the early recognition of environmental threats and enable more effective and timely responses. Therefore, we propose that:

- P1: More experienced managers have more ability to perceive standards faster than less experienced managers (see Figure 3.2.1).

APA (2018) defines attention as "a state of awareness focused on a subset of available perceptual information". Attention is critical to perception. Attention determines which stimuli are recognized and identified by focusing on specific information (Pearson \& Kosslyn, 2015). Posner and Petersen (1990) point out three main functions that have been preeminent in cognitive accounts of attention: 1 . orientation to sensory events; 2 . detection of signals for (conscious) focal processing; and 3. alertness.

To some extent, the brain can respond to the information contained in the sensory stimuli through automatic mental activities. Automatic mental processes help to preserve the use of limited brain attention capacity (Weber \& Johnson, 2009). For example, a phenomenon called pop-out occurs when a stimulus differs sufficiently from its surroundings and automatically draws our attention (Pearson \& Kosslyn, 2015). In contrast, during the active search for a particular feature, object or event, the brain relies on controlled processing to focus attention (Posner \& Fernandez-Duque, 1999).

Posner and Petersen (1990) proposed the existence of an executive attentional system that can play a role by orchestrating various parts of an attentional system within the brain (Rueda, Posner, \& Rothbart, 2005). Practice and training can improve attention capabilities by providing a source of path dependency.

Ocasio and Joseph (2018) propose the attention based-view (ABV). According to the authors, the origins of the ideas behind a grand strategy are less important than the organization's ability to sustain focused attention on the development, implementation, and elaboration of good ideas in a distinctive strategic agenda for value creation.

The transformation of ideas into an optimal strategy is shaped by the company's identity and corresponding patterns of organizational attention (Ocasio \& Joseph, 2018). Moreover, the major strategies focus attention on 
creating value for the customer, by proposing the company's value and business model. Great strategies emerge from a strategic agenda that is focused, communicated and distributed throughout the organization (Ocasio \& Joseph, 2018).

Attention is a topic of interest in strategic management (Ocasio, 1997; Ocasio \& Joseph, 2018) and in cognitive neuroscience (Posner, 2004). In strategy, attention raises questions in problem identification (Lyles, 1981; Starbuck \& Milliken, 1988), solving problems (Bower, 1967; Newell \& Simon, 1972), resource allocation (Ansoff, 1965; Bower, 1970), diagnosis of strategic issues (Dutton, Fahey, \& Narayanan, 1983) and organizational mindfulness (Hyland, Lee, \& Mills, 2015). These topics offer many points of contact with cognitive neuroscience (Powell, 2011).

Detecting opportunities and threats in an uncertain, complex and often accelerated environment requires acute cognitive skills in relation to attention. By focusing on relevant stimuli, attention can facilitate environmental scanning. In addition, the alert component of care can facilitate the detection and creation of new opportunities, while the capacity for guidance directs the relevant information. Thus, the cognitive capability of attention provides a basis for dynamic managerial detection capabilities. Therefore, we have as a proposition:

- P2: The greater the attention of a strategic manager, the greater will be his/her perception capability to solve problems (see Figure 3.2.1).

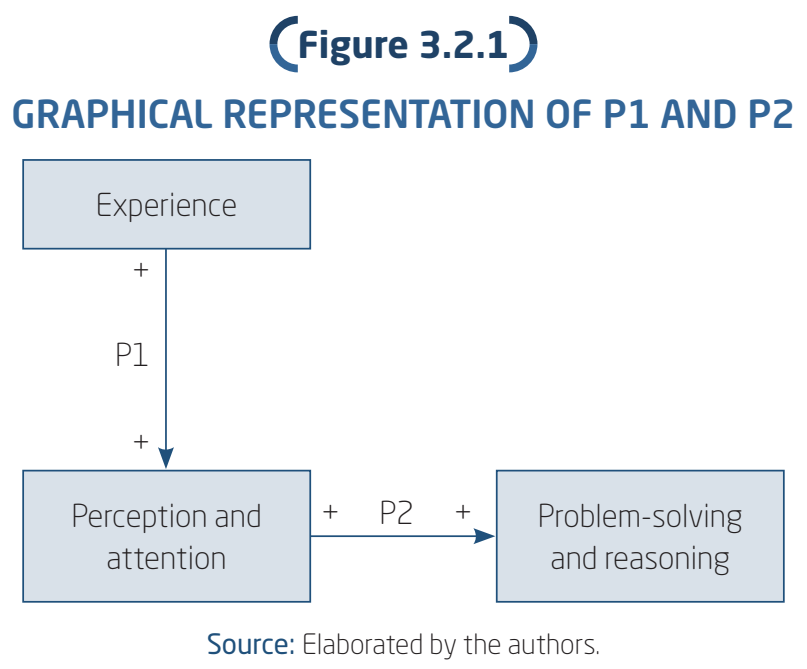




\subsection{Problem-solving and rationality}

For Gazzaniga (2014), problem-solving refers to finding a way around an obstacle to achieving an objective, where an obstacle denotes a problem. Reasoning refers to evaluating information, arguments, and beliefs to draw a conclusion or using information to determine whether a conclusion is valid or reasonable (Gazzaniga, 2014).

The Oxford Dictionary of Psychology (Colman, 2006) provides a narrower definition of "reasoning" as mental activities "aimed at finding solutions to problems by applying formal logic rules or some other rational procedure". Given the close relationship between problem-solving and reasoning, we discuss both together.

Controlled mental processing comes into play in the application of formal rules of logic or other rational approaches to problem-solving, and is associated with factors such as "fluid intelligence" and "rational thinking dispositions" (also called "cognitive styles") (Stanovich, 2009, pp. 28-40). Fluid intelligence is based on short-term memory and involves the ability to reason without relying heavily on previously learned knowledge or procedures (Pearson \& Kosslyn, 2015).

In contrast, thinking dispositions have to do with a person's "cognitive propensities", such as tendencies to "think broadly about a problem before responding, gauge the strength of one's opinion according to the amount of evidence available, think on future consequences before acting [...] and explicitly weighing pros and cons of a situation" (Stanovich, 2009, pp. 31-32). These factors are involved in the capability to regulate our thinking and to replace automatic responses (Stanovich, 2009).

Besides the dependency of the controlled processing, problem-solving can use a more automatic "heuristic processing", "designed to take you to some extent to solve a problem or make a decision" (Stanovich, 2009, p. 23). For Gigerenzer and Gaissmaier (2011), the heuristic consists of cognitive processes employed in non-rational decisions, being defined as strategies that ignore part of the information with the objective of making the choice easier and faster. Rather than relying on extensive multi-choice analysis, this approach is based on shortcuts (Pearson \& Kosslyn, 2015). The brain can rely on heuristics when working on ill-defined problems (Pearson \& Kosslyn, 2015) or solving well-defined but complex problems such as those encountered in chess (Pearson \& Kosslyn, 2015).

Frederick (2005, p. 26) proposed a "cognitive reflection test" to measure the degree to which an individual uses automatic versus controlled processing 
in decision-making. With this test, Frederick (2005) found that individuals who depended more heavily on the controlled mental process (showed greater cognitive reflection) were more willing to defer monetary rewards when provided a substantially greater gain and were less subject to prejudgement about taking a risk for gains versus losses. These results suggest that the benefits of controlled mental processing counteract possible biases in decision-making for a comprehensive review of such trends (Kahneman, 2011; Waraich, 2016).

In another study, Payne, Bettman, and Johnson (1988) investigated decision-making when individuals faced time constraints and had to choose the most valuable result among sets of monetary rewards with different probabilities of occurrence. They found that some heuristics led to results that were equally or more accurate than those obtained using controlled mental processing in the same position while requiring substantially less mental effort (Payne et al., 1988). These results suggest that the effectiveness of automatic versus controlled processing in problem-solving may depend in part on the characteristics of the situation, such as time pressure.

Decisions to seize opportunities through strategic investments are likely to require reasoning and problem-solving skills to develop investment options and assess their potential for profit. The design of the business model may also require problem-solving skills, insofar as successful business models have an underlying logic (Wirtz, Pistoia, Ullrich, \& Göttel, 2016). The design and successful implementation of business models require several design elements that involve strategic fit and complementarity between activities (Foss \& Saebi, 2017).

A cognitive ability to solve problems can help managers to link the myriad characteristics of a business model. The thinking ability of fluid intelligence can help solve problems related to both strategic investment and business model design.

Thought arrangements that promote careful consideration of alternative options can also help a person seize opportunities. Moreover, while the use of controlled mental processing can help managers guard against cognitive defects in the valuation of investment options, heuristics may prove to be particularly effective in some situations, such as when managers face rigorous time pressures to take decisions, or when problems are complex or poorly defined. In this regard, propositions $3 \mathrm{a}$ and $3 \mathrm{~b}$ are formulated (see Figure 3.3.1):

- P3a: The shorter the time for a manager to decide, the lower will be his cognitive capability to solve problems. 
- P3b: The complexity of the problem moderates the relationship between the time taken by a manager to make a decision and his cognitive capability to solve the problem.

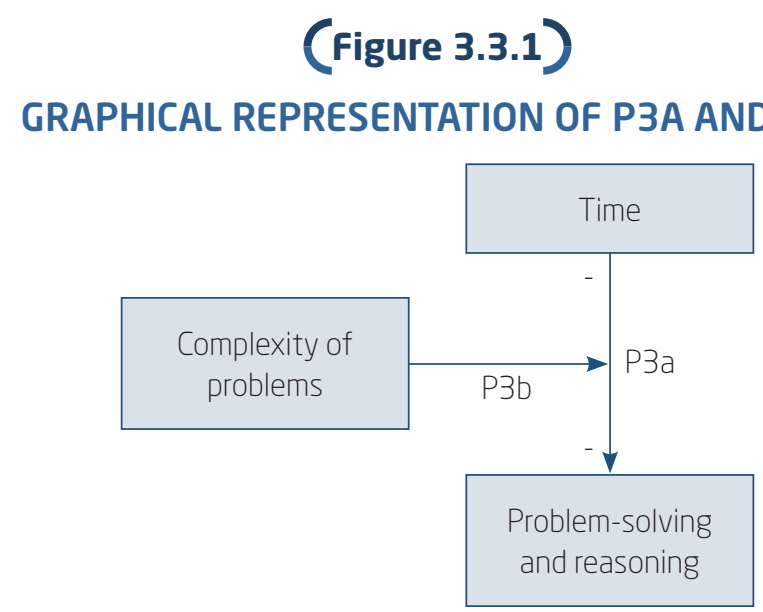

Source: Elaborated by the authors.

\subsection{Language and communication}

Cognitive capability in the language domain is closely related to other cognitive capabilities. However, based on tests, measurements and observational studies, language skills tend to coexist separately from other skills. Carroll (1993) provides evidence that, in most cases, the language domain factor is differentiated from other factors such as reasoning, memory and perceptual speed.

The domain of language encompasses a range of cognitive capabilities. Carroll (1993) distinguishes between oral language (listening and speaking) and written and printed language (reading and writing), and between language reception (listening and reading) and language production (speaking and writing). Based on a synthesis of research on language skills, Dörnyei and Ryan (2015) argue that the extent of controlled processing in language use varies according to the type of linguistic skill. Writing, for example, presents more adherence to controlled mental processing than talking (Dörnyei \& Ryan, 2015).

Non-verbal behavior, such as facial expressions and gestures, may also convey a variety of information, including that related to opinions, values, cognitive state such as understanding or confusion, and physical state such 
as fatigue, and emotions (DePaulo, 1992). People can use non-verbal behaviors instead of verbal communication or to complement it (DePaulo, 1992).

DePaulo (1992) argues that nonverbal behaviors vary along a "continuum of controllability" - that is, some nonverbal behaviors are largely automatic, while others have the potential for deliberate self-control. DePaulo (1992) suggests that deliberate non-verbal behaviors can become automatic.

Asset reconfiguration can critically depend on the ability of strategic managers to persuade others in their organization to undertake new initiatives. Language can be used to communicate broad goals in order to promote alignment between different parts of an organization (Barnard, Barnard, \& Andrews, 1968).

The communication style of top managers in general, and how they communicate a vision for the organization, can inspire workers, encourage initiative and drive business growth (Mayfield, Mayfield, \& Sharbrough, 2015). Managerial capability in language use, such as improvised conversations, word flow and articulation in conversation, can affect workers' response to change initiatives.

Non-verbal communication, such as facial expressions and gestures, can further affect the workers' response. In addition, CEOs' and entrepreneurs' use of metaphorical language can facilitate strategic change within organizations and direct alignment by orienting members towards common goals (Hill \& Levenhagen, 1995). Thus, based on cognitive science research, Shaw, Brown, and Bromiley (1998) advise managers to hone their storytelling skills as a means of motivating and mobilizing an organization around a new strategic plan. Others have noted the importance of management narrative in knowledge transfer (Swap, Leonard, \& Shields, 2001), driving innovation and persuading others to follow their lead (Conger, 1998). In this way:

- P4: The greater the communication capability of the manager, the greater will be his/her capability for: a. perception and attention and b. problemsolving (see Figure 3.4.1). 


\section{(Figure 3.4.1)}

GRAPHICAL REPRESENTATION OF P4A AND P4B

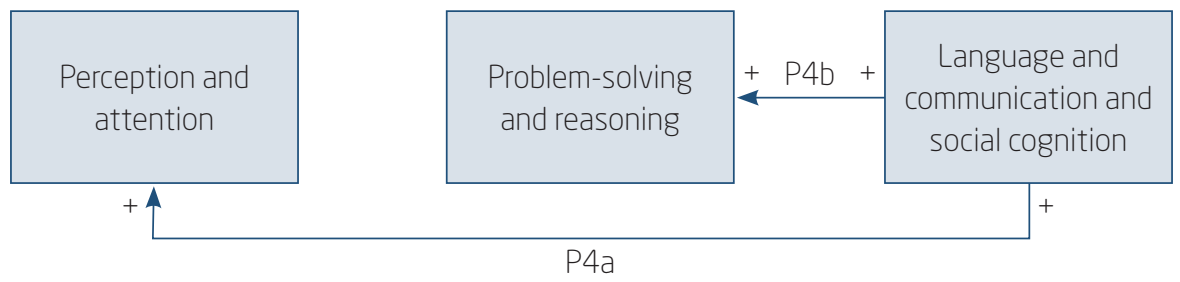

Source: Elaborated by the authors.

\subsection{Social cognition}

Social cognition is a complex phenomenon that encompasses many types of mental activity, such as attention and memory (Fiske, 2018), with close links to emotion and the affective system of the brain (Fiske, 2018). Based on evidence from developmental science, social psychology and neuroscience, Decety and Sommerville (2003) argue that the processing of socially relevant information occurs in specific areas of the brain, suggesting that social cognitive capabilities play a distinct cognitive function. That is, the mental activities involved in social cognition, such as attention, perception and reasoning, seem to relate specifically to the social aspects of an individual's external environment (Greifeneder, Bless, \& Fiedler, 2017).

Social cognitive capabilities seem to involve automatic and controlled mental processing. For example, assigning intentions to others seems to be automatic (Kolb \& Whishaw, 2009), because social perception is largely automatic (Bargh \& Chartrand, 1999). In contrast, controlled processing comes into play in setting goals for social behavior and self-monitoring of progress to achieve those goals (Moskowitz, 2005).

Bargh and Chartrand (1999), however, argue that goals such as impression formation can also be activated automatically, and that practice in setting goals in the same circumstances can lead to automation. In general, based on an analysis of brain imaging studies related to social cognition, Lieberman (2007) argues that a range of social cognitive capabilities may involve both automatic and controlled processes. The brain image showed that trust is associated with specific neurological mechanisms and associated mental activities that allow people to attribute credit or blame for shared outcomes (Tomlin et al., 2006). 
Social cognitive capability includes the ability to understand others' point of view, and therefore also has the potential to influence other people's behavior (Helfat \& Peteraf, 2015). The social cognitive capabilities of top executives can allow them to influence organizational members to promote asset reconfiguration. These capabilities can help managers to foster cooperation. Cooperation is often associated with trust between members of the organization; trust can also serve to reduce coordination costs (Zhong, Su, Peng, \& Yang, 2017). The ability of key executives to trust and promote trust is likely to depend in part on their social cognitive capabilities since trust requires mutual understanding. Thus, the fifth proposition is as follows:

- P5: The greater the social cognitive capability of the manager, the greater will be the level of trust shared by his/her team (see Figure 3.5.1).

\section{(Figure 3.5.1) \\ GRAPHICAL REPRESENTATION OF P5}

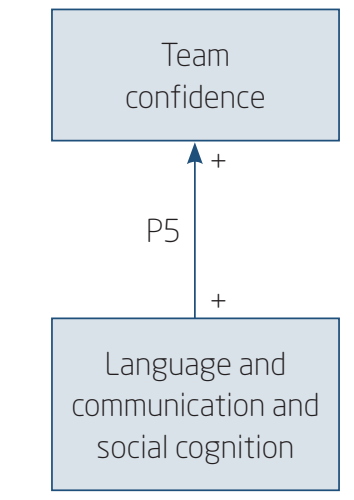

Source: Elaborated by the authors.

Managers can also use social cognitive capabilities to try to overcome organizational resistance to change. These resources can provide insight into how members of the organization perceive change which, in turn, can enable top managers to offer better incentives to change or frame their communications about change more effectively.

The concept of strategic change has been extensively addressed in research on managerial and cognitive dynamic capacities (Helfat \& Martin, 2015). Strategic changes refer to those changes that need to be implemented in organizations that are subject to a complex and changing environment, 
making dialogue between the concept of dynamic cognitive capabilities and the strategic changes necessary, since these two concepts have been shown to be related in 21 researches between 1980 and 2013 documented in the bibliographic survey by Helfat and Martin (2015).

Social cognitive capabilities may also be significant in managing power relations among organizational members (Casciaro et al., 2015), which is important in overcoming organizational inertia and barriers to change (Heyden, Fourné, Koene, Werkman, \& Ansari, 2017).

The arguments preceding the theoretical exposition that underlies the propositions are condensed in Figure 3.5.2. Thus, in addition to automatic and controlled mental processing, the existence of prior experience, time constraints, level of complexity of problems, and the level of cooperation and confidence of the team may exert an influence, or be influenced by, perception and attention, problem-solving, reasoning, language and communication, and social cognition.

\section{(figure 3.5.2)}

\section{MENTAL MODEL OF APPLICATION OF COGNITIVE DYNAMIC CAPABILITY}

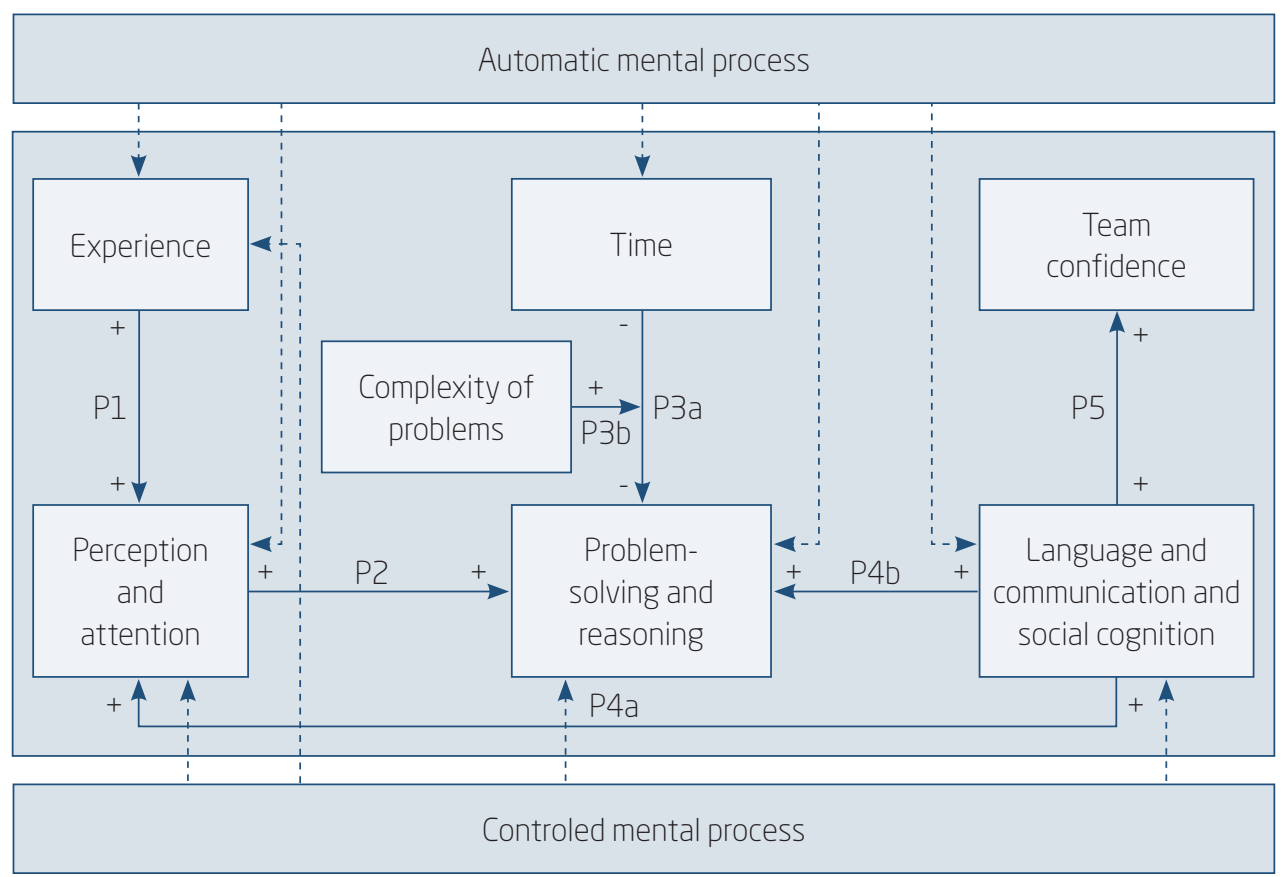

Source: Elaborated by the authors. 
In Figure 3.5.2, the continuous arrows represent the five propositions formulated. The direction of the arrows indicates the possible dependency relations between the variables. The signs at the ends of the arrows indicate whether the relationship is positive or negative between the variables. The dotted arrows in the framework indicate possible links identified in the literature between automatic and controlled mental processing and other constructs. Indicating these points of contact is already a contribution, although it was not possible to formulate propositions, this being one of the limitations of this study. These variables represent, theoretically, the cognitive dynamic capability of managers.

Clearly, these are not the only propositions that can be formulated in the process of improving research on cognitive dynamic capabilities. They are probably a good starting point for future research efforts since they cover aspects of cognitive psychology applied to the context of dynamic capacities.

\section{THEORETICAL AND EMPIRICAL IMPLICATIONS}

Cognitive dynamic capability stands out because capabilities, in general, encompass the ability to perform not only physical but also mental activities. For managers faced with the need to develop and implement strategic changes, this concept becomes more coherent, assuming peculiar importance.

It was possible to establish a concept in line with the proposed mental model. In this sense, the cognitive dynamic capability has been defined here as the ability of an individual manager to perform automatic and controlled mental activities, whose consequences are reflected in strategic changes in business models and firm performance.

We also analyzed the role of automatic and controlled mental processes and how they interrelate with aspects such as perception and attention, problem-solving and reasoning, language and communication, and social cognition. From this analysis, it was possible to formulate five propositions that can explain the implications and relationships among those displayed constructs (see Figure 3.5.2). It should be emphasized that the formulation of these propositions extrapolated the initial contribution of Helfat and Peteraf (2015), since the authors did not explicitly formulate them, although they presented several examples of empirical applications mainly related to psychology; nor did they propose and sign among them, including the force of moderation. 
The study also demonstrated how heterogeneity and path dependence associated with cognitive capabilities are likely to produce heterogeneity of managerial dynamic capability among strategic managers (Helfat \& Peteraf, 2015; Levine, Bernard, \& Nagel, 2017). While some managers may have more effective cognitive capabilities than others, this does not simply mean that some managers are smarter than others. What constitutes intelligence is a subject of ongoing debate. Furthermore, other factors, such as thinking dispositions, are distinct from intelligence but are particularly important for problem-solving and reasoning capabilities (Helfat \& Peteraf, 2015; Schilling, 2018).

In addition, individual managers may not be equally qualified in all types of mental activity. If some types of cognitive capabilities are more important to certain dynamic capabilities than others and are distributed heterogeneously among managers, managers with superior abilities to detect opportunities, for example, may not necessarily have superior abilities to reconfigure business models.

Related research suggests that entrepreneurs, who are involved in detecting opportunities, and mature business managers, who need to reconfigure the business model, differ in their cognition (specifically, their heuristics and decision-making biases) (Busenitz \& Barney, 1997). In this sense, it would be useful to investigate how cognitive capabilities contribute to the heterogeneity of dynamic managerial capabilities in different types of company.

With respect to managerial dynamic capabilities to detect opportunities and reconfigure business, the emphasis is on ways in which strategic management can shape aspects of the organizational context, such as encouraging cooperation, reducing resistance to change, designing a new business model, and investing in new skills and assets. This suggests that managerial cognitive capabilities can act as mediators of the relationship between changes in organizational context and strategic change, which can, in turn, affect company performance.

While it is possible to point to preeminent examples of CEOs who have successfully restructured their organizations, such as Lou Gerstner at IBM (Harreld, O'Reilly, \& Tushman, 2007) and Steve Jobs at Apple (Streeter, 2015), other CEOs have been less successful - for example, Kodak's CEOs, who did not believe in the forces of change in their industry, which resulted in the company filing for bankruptcy. This sad ending for an iconic company raises the question of whether Kodak's CEOs lacked the necessary cognitive capabilities and other dynamic managerial capabilities, or whether the 
organizational context would have harmed even the most qualified CEO. That is to say, even executives with higher cognitive capabilities may face limits on their perceptions and readings of the environment. Such limits may arise from misunderstandings between political coalitions rooted in a firm, rigid organizational identity, or insufficient financial resources, to name but a few possibilities. Getting a better understanding of the boundaries that some organizational contexts can place on dynamic managerial capabilities, and the sources of those boundaries, would be a fruitful endeavor.

In addition, in an analysis of IBM's transition to mainframe computing, Taylor and Helfat (2009) noted ways in which groups of middle managers helped to transform shared organizational cognition. Repeated communication with others in the organization - an aspect of cognitive capabilities for reconfiguration - was instrumental in promoting such change, suggesting that explicit consideration of cognitive capabilities at the level of the average manager could provide additional information about the process of strategic change.

\section{FINAL REMARKS}

We focused on the cognitive capabilities of the strategic manager. Other people can affect strategic changes in organizations, including senior management team members, general business unit managers (Martin, 2011) and middle managers (Taylor \& Helfat, 2009). Analyzing the cognitive capabilities of managers below the executive top level enriches the understanding of strategic changes (Helfat \& Martin, 2015). For example, in a study of dynamic managerial skills at the general manager level in multibusiness software companies, Martin (2011) found that managers worked sporadically as teams to sense and seize opportunities, but this author did not investigate the role of cognition.

We also suggest empirically testable propositions. For example, companies that have strategic managers with superior cognitive capabilities for sensing and seizing may be more likely to gain advantages by anticipating movements. Strategic managers who pay more attention and more accurately perceive the emerging changes in technology and customer demand are more likely to sense new opportunities, and can, therefore, move faster. By leveraging the new opportunities, strategic managers who have superior capabilities for problem-solving and reasoning are likely to make smarter investments and design better business models, increasing the likelihood 
that their companies can gain long-term benefits by moving in advance. Furthermore, when conditions change enough to justify reconfiguring strategic assets, companies can perform these reconfigurations more quickly and with fewer consequences when strategic managers have the capabilities of communication, language, and higher social cognition.

This work contributes to the literature insofar as it provides a review of the sources and characteristics of cognitive dynamic capability, explains and models cognitive management capacities, and points out the role of cognitive aspects related to strategic changes and business models. In management terms, it demonstrates how cognition can help explain why some managers have more effective capabilities to anticipate, interpret and respond to demands in an evolving environment.

Finally, this analysis suggests a research opportunity on the relationships among managerial cognitive capabilities and organizational dynamic capabilities. For example, managerial dynamic resources and managerial cognitive capabilities can help create, extend or modify organizational capabilities (including dynamics), that in turn affect firm performance. In addition, organizational dynamic capabilities and their underlying routines may involve managerial inputs and decisions (for example, choosing R\&D projects, acquiring assets, partnering with suppliers), so that the managerial dynamic capabilities and their associated cognitive capabilities intertwine with organizational dynamic capacities. Comprehending the relationships between managerial and organizational capabilities, theoretically and empirically, remains a largely unexplored but an important ground for future research.

\section{UMA CONTRIBUIÇÃO À ESTRUTURA TEÓRICA PARA A CAPACIDADE DINÂMICA COGNITIVA}

\section{RESUMO}

Objetivo: Contribuir para a estrutura teórica da capacidade dinâmica cognitiva.

Originalidade/valor: Este artigo fornece uma revisão das fontes e características das capacidades gerenciais cognitivas, aponta suas dimensões específicas de análise e explora as possibilidades de pesquisa associadas 
a abordagens como mudanças estratégicas, modelos de negócios e desempenho da firma.

Design/metodologia/abordagem: Este trabalho utiliza-se do conceito de modelo mental, entendido aqui como estruturas de conhecimento simplificadas ou representações cognitivas sobre o funcionamento do ambiente empresarial (Gary \& Wood, 2011), para expor o encadeamento lógico das reflexões teóricas e formulação de proposições.

Resultados: As contribuições principais deste estudo são as seguintes: 1. a reformulação do conceito de capacidade dinâmica cognitiva; 2. a inclusão dos conceitos de processamento mental controlado e automático no modelo proposto; 3. a inclusão das variáveis experiência, tempo, confiança da equipe e complexidade; e 4. a formulação de cinco proposições para subsidiar aplicações empíricas futuras. A análise sugere oportunidade de pesquisa sobre a relação entre capacidades dinâmicas gerenciais, cognitivas e organizacionais, e suas contribuições conjuntas para mudanças estratégicas nos modelos de negócios e no desempenho da firma.

\section{PALAVRAS-CHAVE}

Modelo mental. Capacidade cognitiva. Capacidade gerencial. Atividades mentais. Microfundamentos.

\section{$\int$ REFERENCES}

Adner, R., \& Helfat, C. E. (2003). Corporate effects and dynamic managerial capabilities. Strategic Management Journal, 24(10), 1011-1025. doi:10.1002/ smj.331

American Psychological Association (2018). Glossary of psychological terms. Recuperado de http://www.apa.org/research/action/glossary.aspx? $\mathrm{tab}=16$

Ansoff, H. I. (1965). Corporate strategy. New York: McGraw-Hill.

Bargh, J. A., \& Chartrand, T. L. (1999). The unbearable automaticity of being. American Psychologist, 54(7), 462-479.

Barnard, C. I., Barnard, C. I., \& Andrews, K. R. (1968). The functions of the executive (Vol. 11). Cambridge, MA: Harvard University Press. 
Bower, J. L. (1967). Strategy as a problem-solving theory of business planning. Boston: Harvard Business School Press.

Bower, J. L. (1970). Managing the resource allocation process. Boston: Harvard Business School Press.

Busenitz, L. W., \& Barney, J. B. (1997). Differences between entrepreneurs and managers in large organizations: Biases and heuristics in strategic decision-making. Journal of Business Venturing, 12(1), 9-30. doi:10.1016/ S0883-9026(96)00003-1

Carroll, J. B. (1993). Human cognitive abilities: A survey of factor-analytic studies. Cambridge, UK: Cambridge University Press.

Casciaro, T., Barsade, S. G., Edmondson, A. C., Gibson, C. B., Krackhardt, D., \& Labianca, G. (2015). The integration of psychological and network perspectives in organizational scholarship. Organization Science, 26(4), 1162-1176. doi:10.1287/orsc.2015.0988

Castanias, R. P., \& Helfat, C. E. (1991). Managerial resources and rents. Journal of Management, 17(1), 155-171. doi:10.1177/014920639101700110

Chase, W. G., \& Simon, H. A. (1973a). Perception in chess. Cognitive Psychology, 4(1), 55-81. doi:10.1016/0010-0285(73)90004-2

Chase, W. G., \& Simon, H. A. (1973b). The mind's eye in chess. In W. G. Chase (Ed.). Visual information processing (pp. 215-281). New York: Academic Press.

Chen, C. M., Delmas, M. A., \& Lieberman, M. B. (2015). Production frontier methodologies and efficiency as a performance measure in strategic management research. Strategic Management Journal, 36(1), 191-236. doi:10. 1002/smj.2199

Colman, A. M. (2006). A dictionary of psychology (2nd ended.). Oxford, UK: Oxford University Press.

Conger, J. A. (1998). The necessary art of persuasion. Harvard Business Review, 76(3), 84-95.

Decety, J., \& Sommerville, J. A. (2003). Shared representations between self and other: A social cognitive neuroscience view. Trends in Cognitive Sciences, 7(12), 527-533. doi:10.1016/j.tics.2003.10.004

DePaulo, B. M. (1992). Nonverbal behavior and self-presentation. Psychological Bulletin, 111(2), 203-243. doi:10.1037/0033-2909.111.2.203

Dörnyei, Z., \& Ryan, S. (2015). The psychology of the language learner revisited. London: Routledge. 
Dutton, J. E., Fahey, L., \& Narayanan, V. K. (1983). Toward understanding strategic issue diagnosis. Strategic Management Journal, 4(4), 307-323. doi:10.1002/smj.4250040403

Eggers, J. P., \& Kaplan, S. (2013). Cognition and capabilities: A multi-level perspective. Academy of Management Annals, 7(1), 295-340. doi:10.5465/19 416520.2013.769318

Ericsson, K. A. (2016). Summing up hours of any type of practice versus identifying optimal practice activities: Commentary on Macnamara, Moreau, \& Hambrick (2016). Perspectives on Psychological Science, 11 (3), 351-354. doi:10.1177/1745691616635600

Ericsson, K. A., \& Lehmann, A. C. (1996). Expert and exceptional performance: Evidence of maximal adaptation to task constraints. Annual Review of Psychology, 47(1), 273-305.

Fiske, S. T. (2018). Controlling other people: The impact of power on stereotyping. In J. DeLamater \& J. Collett (Eds.). Social cognition (pp. 101-115). New York: Routledge.

Foss, N. J., \& Saebi, T. (2017). Fifteen years of research on business model innovation: How far have we come, and where should we go? Journal of Management, 43(1), 200-227. doi:10.1177/0149206316675927

Frederick, S. (2005). Cognitive reflection and decision making. The Journal of Economic Perspectives, 19(4), 25-42. doi:10.1257/089533005775196732

Fredrickson, J. W., \& Mitchell, T. R. (1984). Strategic decision processes: Comprehensiveness and performance in an industry with an unstable environment. Academy of Management Journal, 27(2), 399-423. doi:10.23 $07 / 255932$

Gary, M. S., \& Wood, R. E. (2011). Mental models, decision rules, and performance heterogeneity. Strategic Management Journal, 32 (6), 569-594. doi:10.1002/smj.899

Gazzaniga, M. S. (Ed.). (2014). Handbook of cognitive neuroscience. London: Springer.

George, N. M., Parida, V., Lahti, T., \& Wincent, J. (2016). A systematic literature review of entrepreneurial opportunity recognition: Insights on influencing factors. International Entrepreneurship and Management Journal, 12(2), 309-350. doi:10.1007/s11365-014-0347-y

Gigerenzer, G., \& Gaissmaier, W. (2011). Heuristic decision making. Annual Review of Psychology, 62, 451-482. doi:10.1146/annurev-psych-120709145346 
Greifeneder, R., Bless, H., \& Fiedler, K. (2017). Social cognition: How individuals construct social reality. London: Psychology Press.

Gul, F. \& Pesendorfer, W. (2008). The case for mindless economics. In A. Caplin \& A. Schotter (Eds). The Foundations of Positive and Normative Economics. New York: Oxford University Press:. 3-39.

Harreld, J. B., O’Reilly, C. A., \& Tushman, M. L. (2007). Dynamic capabilities at IBM: Driving strategy into action. California Management Review, 49(4), 21-43. doi:10.2307/41166404

Helfat, C. E., \& Martin, J. A. (2015). Dynamic managerial capabilities: Review and assessment of managerial impact on strategic change. Journal of Management, 41 (5), 1281-1312. doi:10.1177/0149206314561301

Helfat, C. E., \& Peteraf, M. A. (2015). Managerial cognitive capabilities and the microfoundations of dynamic capabilities. Strategic Management Journal, 36(6), 831-850. doi:10.1002/smj.2247

Heyden, M. L., Fourné, S. P., Koene, B. A., Werkman, R., \& Ansari, S. (2017). Rethinking "top-down" and "bottom-up" roles of top and middle managers in organizational change: Implications for employee support. Journal of Management Studies, 54(7), 961-985. doi:10.1111/joms.12258

Hill, R. C., \& Levenhagen, M. (1995). Metaphors and mental models: Sensemaking and sensegiving in innovative and entrepreneurial activities. Journal of Management, 21 (6), 1057-1074. doi:10.1016/0149-2063(95) 90022-5

Hyland, P. K., Lee, R. A., \& Mills, M. J. (2015). Mindfulness at work: A new approach to improving individual and organizational performance. Industrial and Organizational Psychology, 8(4), 576-602. doi:10.1017/iop.2015.41

Kahneman, D. (2011). Thinking fast and slow. New York: Farrar, Straus and Giroux.

Kahneman, D., Slovic, P., \& Tversky, A. (1982). Judgment under uncertainty: Heuristics and biases. New York: Cambridge University Press.

Kolb, B., \& Whishaw, I. (2009). Fundamentals of human neuropsychology. New York: Worth Publishers.

Krackhardt, D. (1990). Assessing the political landscape: Structure, cognition, and power in organizations. Administrative Science Quarterly, 35(2), 342-369. doi:10.2307/2393394

Larrick, R. P., \& Feiler, D. C. (2016). Expertise in decision making. In G. B. Keren \& G. Hu (Eds.). The Wiley-Blackwell Handbook of Judgment and Decision Making (pp. 696-721). Malden, MA: Blackwell. 
Levine, S. S., Bernard, M., \& Nagel, R. (2017). Strategic intelligence: The cognitive capability to anticipate competitor behavior. Strategic Management Journal, 38(12), 2390-2423. doi:10.1002/smj.2660

Lieberman, M. D. (2007). Social cognitive neuroscience: A review of core processes. Annual Review of Psychology, 58, 259-289. doi:10.1146/annurev. psych.58.110405.085654

Lieberson, S., \& O’Connor, J. F. (1972). Leadership and organizational performance: A study of large corporations. American Sociological Review, 37(2), 117-130. doi:10.2307/2094020

Luger, G. F. (1994). Cognitive science: The science of intelligent systems. San Diego, CA: Academic Press.

Martin, J. A. (2011). Dynamic managerial capabilities and the multibusiness team: The role of episodic teams in executive leadership groups. Organization Science, 22(1), 118-140. doi:10.1287/orsc.1090.0515

Mayfield, J., Mayfield, M., \& Sharbrough III, W. C. (2015). Strategic vision and values in top leaders' communications: Motivating language at a higher level. International Journal of Business Communication, 52(1), 97-121. doi:10. $1177 / 2329488414560282$

Moskowitz, G. B. (2005). Social cognition: Understanding self and others. New York: Guilford Press.

National Advisory Mental Health Council (1996). Basic behavioral science research for mental health: Perception, attention, learning, and memory. American Psychologist, 51 (2), 133-142.

Newell, A., \& Simon, H. A. (1972). Human problem solving. Englewood Cliffs, NJ: Prentice Hall.

Ocasio, W., \& Joseph, J. (2018). The attention-based view of great strategies. Strategy Science, 3(1), 289-294. doi:10.1287/stsc.2017.0042

Payne, J. W., Bettman, J. R., \& Johnson, E. J. (1988). Adaptive strategy selection in decision making. Journal of Experimental Psychology: Learning, Memory, and Cognition, 14(3), 534-552. doi:10.1037/0278-7393.14.3.534

Pearson, J., \& Kosslyn, S. M. (2015). The heterogeneity of mental representation: Ending the imagery debate. Proceedings of the National Academy of Sciences, 112(33), 10089-10092. doi:10.1073/pnas.1504933112

Posner, M. I. (Ed.). (2004). Cognitive neuroscience of attention. New York: Guilford Press.

Posner, M. I., DiGirolamo, G. J., \& Fernandez-Duque, D. (1997). Brain mechanisms of cognitive skills. Consciousness and Cognition, 6(2), 267-290. doi:10.1006/ccog.1997.0301 
Posner, M. I., \& Fernadez-Duque, D. (1999). Attention in the human brain. In R. A. Wilson \& F. C. Keil (Eds.). The MIT encyclopedia of the cognitive sciences. Cambridge, MA: MIT Press.

Posner, M. I., \& Petersen, S. E. (1990). The attention system of the human brain. Annual Review of Neuroscience, 13(1), 25-42. doi:10.1146/annurev. ne.13.030190.000325

Powell, T. C. (2011). Neurostrategy. Strategic Management Journal, 32 (13), 1484-1499. doi:10.1002/smj.969

Powell, T. C. (2014). Strategic management and the person. Strategic Organization, 12(3), 200-207. doi:10.1177/1476127014544093

Powell, T. C., Lovallo, D., \& Caringal, C. (2006). Causal ambiguity, management perception, and firm performance. Academy of Management Review, 31 (1), 175-196. doi: 10.2307/20159191

Rueda, M. R., Posner, M. I., \& Rothbart, M. K. (2005). The development of executive attention: Contributions to the emergence of self-regulation. Developmental Neuropsychology, 28(2), 573-594. doi:10.1207/s15326942 dn2802_2

Rumelt, R. P., Schendel, D., \& Teece D (Eds.). (1994). Fundamental issues in strategy: A research agenda. Boston, MA: Harvard Business School Press.

Schilling, M. A. (2018). The cognitive foundations of visionary strategy. Strategy Science, 3(1), 335-342. doi:10.1287/stsc.2017.0044

Schneider, S. C., \& Angelmar, R. (1993). Cognition in organizational analysis: Who's minding the store? Organization Studies, 14(3), 347-374. doi:10.1177/017084069301400302

Schneider, W., \& Shiffrin, R. M. (1977). Controlled and automatic human information processing: I. Detection, search, and attention. Psychological Review, 84(1), 1-66. doi:10.1037/0033-295X.84.1.1

Shaw, G., Brown, R., \& Bromiley, P. (1998). Strategic stories: How 3M is rewriting business planning. Harvard Business Review, 76(3), 41-42.

Stanovich, K. E. (2009). What intelligence tests miss: The psychology of rational thought. New Haven, CT: Yale University Press.

Stanovich, K. E., \& West, R. F. (2000). Individual differences in reasoning: Implications for the rationality debate? Behavioral and Brain Sciences, 23(5), 645-665. doi:10.1017/CBO9780511808098.026

Starbuck, W. H., \& Milliken, F. J. (1988). Executives' perceptual filters: What they notice and how they make sense. In D. C. Hambrick (Ed.). The executive effect: Concepts and methods for studying top managers (pp. 35-65). Greenwich, CT: JAI Press. 
Streeter, T. (2015). Steve Jobs, romantic individualism, and the desire for good capitalism. International Journal of Communication, 9, 3106-3124.

Swap, W., Leonard, D., \& Mimi Shields, L. A. (2001). Using mentoring and storytelling to transfer knowledge in the workplace. Journal of Management Information Systems, 18(1), 95-114. doi:10.1080/07421222.2001.11045668

Taylor, A., \& Helfat, C. E. (2009). Organizational linkages for surviving technological change: Complementary assets, middle management, and ambidexterity. Organization Science, 20(4), 718-739. doi:10.1287/orsc.1090.0429

Tomlin, D., Kayali, M. A., King-Casas, B., Anen, C., Camerer, C. F., Quartz, S. R., \& Montague, P. R. (2006). Agent-specific responses in the cingulate cortex during economic exchanges. Science, 312(5776), 1047-1050. doi:10. 1126/science. 1125596

Waraich, T. N. (2016). Cognitive reflection and decision making (Doctoral dissertation, Lahore School of Economics, Lahore, Pakistan).

Weber, E. U., \& Johnson, E. J. (2009). Mindful judgment and decision making. Annual Review of Psychology, 60, 53-85. doi:10.1146/annurev. psych.60.110707.163633

Wirtz, B. W., Pistoia, A., Ullrich, S., \& Göttel, V. (2016). Business models: Origin, development and future research perspectives. Long Range Planning, 49(1), 36-54. doi:10.1016/j.lrp.2015.04.001

Zhang, X. A., Li, N., Ullrich, J., \& Dick, R. van (2015). Getting everyone on board: The effect of differentiated transformational leadership by CEOs on top management team effectiveness and leader-rated firm performance. Journal of Management, 41 (7), 1898-1933. doi:10.1177/0149206312471387

Zhong, W., Su, C., Peng, J., \& Yang, Z. (2017). Trust in interorganizational relationships: A meta-analytic integration. Journal of Management, 43(4), 1050-1075. doi:10.1177/0149206314546373

\section{AUTHOR NOTES}

Elnivan M. Souza, Programa de Pós-Graduação em Administração de Empresas, Universidade de Fortaleza (Unifor); e Sérgio Henrique A. C. Forte, Escola de Administração de Empresas de São Paulo, Fundação Getulio Vargas (FGV).

Elnivan M. de Souza is now head of research and assistant professor at campus Dom Luis at Centro Universitário Christus (Unichristus); Sérgio Henrique A. C. Forte is now associate professor at Centro de Ciências de Comunicação e Gestão at Universidade de Fortaleza (Unifor). Correspondence concerning this article should be addressed to Elnivan M. Souza, Avenida Dom Luis, 911, Meireles, Fortaleza, Ceará, Brazil, CEP 60160-230.

E-mail: elnivan@hotmail.com 
A contribution to the theoretical structure for cognitive dynamic capability

EDITORIAL BOARD

Editors-in-chief

Janette Brunstein

Silvia Marcia Russi de Domênico

Associated Editor

Rafael Porto

Technical Support

Vitória Batista Santos Silva

\section{EDITORIAL PRODUCTION}

Publishing Coordination

Jéssica Dametta

Layout Designer

Emap

Language Editor

Daniel de Almeida Leão

Graphic Designer

Libro 